\title{
TAXES AS MOTIVATORS AND PREDICTORS OF COMPANY RESTRUCTURING
}

Prof. dr. sc. Dario Stevanato*

\author{
UDK: $347.72 .04: 336$ \\ https://doi.org/10.30925/zpfsr.39.4.6 \\ Ur.: 7. rujna 2018. \\ Pr.: 20. listopada 2018. \\ Izvorni znanstveni rad
}

\section{Summary}

There seems to be a common pattern in the way Member States have addressed taxation of company reorganizations. After some uncertainty, operations affecting corporate and shareholding structures were considered as sources of taxable capital gains. As might have been expected, this hindered a more efficient capital allocation, leading to the enforcement of special laws granting limited and conditional exemption aiming to ease the transfer of undertakings, often with extra advantages than what would be necessary. A deeper rethinking about the very nature of corporate finance transactions at a later stage defined the problem and brought an across-the-board enactment of general provisions for corporate restructuring, inspired by tax-neutrality: roll-over relief and tax deferral, further underpinned by Community law, have since become standards for addressing mergers, divisions, and, to some extent, transfer of assets and exchange of shares. It is arguable whether tax neutrality granted to reorganizations does represent a waiver to the realization principle, or whether instead it is a consistent development of the legal concept of taxable income. In the former case there would be some grounds to challenge tax neutrality in company restructuring operations that lack commercial reasons through purposive construction or anti-abuse clauses or principles. In the latter, antiavoidance rules should be limited to thwart circumvention of the statutory scope and the spirit of tax law, irrespective of the business purposes of the transactions carried out.

Keywords: company restructuring; roll over relief; cross-border mergers and acquisitions; tax avoidance; business purpose.

* Dario Stevanato, Ph.D., Full Professor, University of Triest, Department of Legal, Language, Interpreting and Translation Studies, Italy; dstevanato@units.it.

This paper is written under support of the Croatian Science Foundation project no. 9366 „Legal Aspects of Corporate Acquisitions and Knowledge Driven Companies' Restructuring and University of Rijeka project no. 13.08.1.2.01 „Protection of Beneficiary on the Croatian and European Financial Services Market“. 


\section{COMPANY RESTRUCTURING: THE LONG ROAD TO FISCAL NEUTRALITY}

For decades, companies' restructurings - encompassing operations such as mergers, divisions, transfers of going concerns, exchanges of shares and so on - have been targeted by academics as well as in the courts for lacking focused legal rules within the framework of ,realized income”. It was quite common to come across opinions that would deem business combinations carried out through mergers or divisions as sources of taxable income in the form of capital gains on transferring companies' assets, warehouse stocks or goodwill, or at the shareholders' level.

Sometimes it was due to pure misconceptions, such as for the treatment of the transformation of companies - the change in the company's legal form - as an incorporation of a new company and the liquidation of the old one. ${ }^{1}$

However, it was with respect to mergers that the realized-income theory came to the foreground. Apparently, in case of a merger, the consolidated company extinguishes or winds up, and its assets and liabilities are transferred to the incorporating company. On this basis, some prominent scholars sustained that mergers should be classified as cases of realized capital gains accrued on the assets of the incorporated company, to be ascertained in the name of the incorporating company as being the overall successor of the former. In other words, mergers were seen as cases of contributions in kind and asset transfers, and thus as sources of taxable capital gains. ${ }^{2}$

That opinion was debunked once it became clear that, from a civil standpoint, corporate mergers do not entail a liquidation of the incorporated company, nor a transfer of assets, and not even an exclusion of the latter from the application of the business tax regime.

Rather than a termination of the legal entities involved and a transfer of assets, mergers imply a pure modification of the statutes of the companies affected by the business restructuring. The incorporated company does not cease existing but goes on „living” within the incorporating company. Accordingly, no real transfer of assets and liabilities takes place, let alone for a consideration.

It was therefore awkward to claim that mergers are chargeable events since capital gains are taxed if realized, id est when the assets are transferred to a third party in exchange for a consideration, or when they fall outside the scope of the business regime in which they are placed, e.g. when their ownership passes on to a private individual or to a non-business legal entity. ${ }^{3}$

In the wake of that achievement tax law expressly excluded mergers as a source of taxable capital gains: within the Italian legal system, for instance, starting from

1 See Uckmar, V., L'imposta di ricchezza mobile sulle plusvalenze patrimoniali, in Aa.Vv., La tassazione delle plusvalenze patrimoniali, Cedam, Padova, 1967, pp. 54-55.

2 Falsitta, G., Realizzo di plusvalenze assoggettabili ad imposta di ricchezza mobile nella fusione di società commerciali, Rivista di diritto finanziario e scienza delle finanze, 1964, I, pp. 643 ff.

3 For a clear and comprehensive explanations of the reasons underlying the tax-neutrality of mergers, in terms of non-realization of the capital gains belonging to the incorporated companies, see Lupi, R., Profili tributari della fusione di società, Cedam, Padova, 1989. 
Art. 16 of D.p.r. no. 598/1973, ${ }^{4}$ which enforced the new corporation income tax, to the current Art. 172 of D.p.r. no. 917/1986, it has been established that mergers do not give rise to the realization or distribution of capital gains and losses of the assets of the merging companies, including those related to the inventory stock and goodwill, and that the same non-realization principle applies also to the accrued capital gains of the shareholders of the merging companies.

After a period of uncertainty, tax neutrality for restructurings involving a change in the statutes of the legal entities affected, such as mergers and divisions, became a standard. Tax neutrality remained, however, bound to the aforementioned transactions (transformation, merger and division) while other business reorganizations and acquisitions taking place through different arrangements - contribution in kind of undertakings, exchange of shares and so on - fell outside the scope of the rule of taxneutrality, with the inherent capital gains taxed on an accrual basis.

A different and longer path has been followed for the transfer of going concerns. Certainly, the selling of assets has always been considered a source of taxable income, in other words as a realized capital gain (or loss). This is not necessarily the case, however, for contributions in kind, namely the transfers of assets in exchange for shares of the company receiving them. As contributions in kind are operations aimed at increasing the capital or the equity reserves of the receiving company, there is reason to treat the contribution not so much as an instrument to cash capital gains, even from the shareholder's perspective, but more as a non-generating income operation.

The tax treatment of contributions in kind has long been uncertain, reflecting the belief that taxable income should stem from a stable and recurrent source, raising cyclic revenues, as in the agricultural paradigm of „tree and fruit”. Income from movable property was addressed by drawing from the long-standing concept of landed income. On top of that, many believed that taxable income should be limited to the excess of production disposable for current expenses without impairment of capital, thus fostering capital gains and the increase of capital as non-taxable items.

Moreover, contribution in kind does not raise any money-income in strict terms as in exchange the transferring company receives shares which, in turn, can be seen as an indirect participation in the same undertaking previously run and not as a kind of consideration (although, to a certain extent, it could be converted to cash). It is indeed a sound reason underpinning contributions in kind as tax-exempt operations: after all, the net wealth of the transferring company or individual receiving the shares of the company whose capital has been increased, reflects the value and plays the same role as the assets transferred. Following the contribution in kind, the transferor still has a stake in the previous business that is in an indirect form, through its holding in the receiving company. ${ }^{5}$ Admittedly, contributions in kind could be considered as ordinary operations involving the receiving of shares in exchange for assets, that is to say as something very similar to a trade-in, if not a sale. Accordingly, the tax exemption for

4 "D.p.r." stands for Decree of the President of the Republic, meaning a legislative decree issued by the Government on the basis of a Parliament's law of delegation.

5 Cf. Stevanato, D., Inizio e cessazione dell 'impresa nel diritto tributario, Cedam, Padova, 1994, pp. $274 \mathrm{ff}$. 
the contribution of undertakings should be seen as an advantage and a deviation from the ordinary income tax rules. ${ }^{6}$ As it is, contributions in kind to company capital are two-fold, being both a partnership and an exchange agreement, and this dual nature is the main reason for long-standing uncertainty in treating the subject for tax purposes.

Indeed, at some point the initial belief about the tax exemption of contributions in kind began to waver, along with the new statutory rule, embedded in the Italian income tax code, that any business's capital increase, ascertained in its financial statements, whether realized or distributed, should be included in the taxable base. ${ }^{7}$

Notwithstanding that the new rule made reference, literally, to money income (price), the final detachment of the assets from the business's transferor and the prospect to consider as ,price” also a consideration in kind, such as shares issued by the receiving company, would persuade the jurisprudence to consider contribution in kind as source of taxable capital gains. ${ }^{8}$ The taxability of in-kind contributions was afterwards definitely affirmed with the tax reform enacted in the early 1970s: since then, the transfer of assets in exchange for shares has had the same tax regime as an asset sale, ${ }^{9}$ with capital gains to be determined - cash consideration lacking - using the market value of the assets transferred to the acquiring company. ${ }^{10}$

The taxability of all types of contribution in kind, however, somehow ironically led to pressures for temporary tax breaks focused on the contribution of undertakings. It soon became clear that by considering contributions in kind as sources of taxable income, the shortcoming was to hinder company restructuring.

As a remedy, the chance was exploited for special regimes aimed at suspending the taxation of transfers of branches of activity in exchange for securities representing the capital of the receiving company. With some mid-seventies statute laws ${ }^{11}$ the taxability of capital gains arising from such transfers was deferred to the selling of the shares received by the transferring company, ${ }^{12}$ while the company whose capital was increased could, for tax purposes, enter the assets received at their market value.

The aim was actually to avoid hampering company restructuring. Nevertheless, the revaluation for tax purposes of the assets in the financial statement of the transferee changed the very nature of the relief: notwithstanding the postponement of the tax due by the transferor, the transferee could immediately deduct amortization, depreciation and capital losses on the market value of the assets. This opportunity gave rise to the exploitation of the tax relief just to achieve a substantive tax break (a tax-free revaluation of the assets transferred) without there being a real business purpose and/ or the need for company restructuring.

6 See Turchi, A., Conferimenti e apporti nel sistema delle imposte sui redditi, Giappichelli, Torino, 2008, pp. 120 ff..

7 Law $1 / 1956$ and D.p.r. 645/1958.

8 On the topic see Turchi, A., op. cit., pp. $25 \mathrm{ff}$.

9 See Art. 9 of the current Italian Income Tax Code (ITC), in which contributions in kind are made equal to transfers with consideration.

10 Except in the case of contribution to the capital of a listed company, in which market's value of the shares is relevant for tax purposes.

11 Reference is in particular made to Laws 170/1965 and 576/1975.

12 The value for tax purposes of the transferred assets was rolled-over the participation received by the transferring company. 
For this reason, subsequent statute laws ${ }^{13}$ put in place a different scheme whereby the tax-exempt transfer of undertakings would bind the receiving company to take over the tax book values of the transferring company, thereby designing the tax-neutrality regime in terms of tax deferral, avoiding permanent abatements and the related risks of tax avoidance.

It is worthwhile noting that the foregoing regimes were just temporary, and sometimes limited to specific categories of taxpayers (small enterprises, banks, etc.). Indeed, it was only with the legislative decree 358/1997 that a comprehensive and stable tax-neutral regime aimed at company restructuring - on which Community law exerted significant influence - was enacted.

Within its provisions, two different regimes for the contribution of undertakings and of relevant participations ${ }^{14}$ were set up: a realization-regime in which any neutrality depends indeed on the maintenance of the assets' tax-book values in the financial statement of the receiving company; ${ }^{15}$ a non-realization regime - aligned to the roll-over relief outlined by the Merger Directive (MD) ${ }^{16}$ - stating that no capital gains or losses are realized by the transferor. In the latter regime the shares received by the transferring company are registered for tax purposes at the same value previously ascribed to the undertaking, while the receiving company carries over the tax values of the assets contributed.

It this fashion, within the general framework of taxation of in-kind contributions according to the realization principle, a special treatment is granted to the contribution of undertakings, thus raising the issue of tracking a clear dividing line between what is a "branch of activity" and what is not, in order not to incur the consequences - in terms of tax not paid and penalties - of a mistaken identification of the operation carried out.

Eventually, in 2008, the above mentioned regimes were split into two: according to Art. 175 of the Italian ITC, the taxability of capital gains arising in the transfer of shares which exceed a certain threshold depends on the values assigned in the account entries of the transferee. ${ }^{17}$ On the other side, Art. 176 grants to contributions in kind of undertakings the roll-over relief and full tax-neutrality, with the receiving company stepping-in the tax values previously ascribed to the transferring company. Considering that the "succession" of tax values can lead to differences with respect to book entries at the market value, the law allows the receiving company to align the values for tax purposes by paying a reduced rate on the hidden capital gains, ${ }^{18}$ which

13 Laws 17/1985 and 218/1990.

14 Id est participations of such an entity to permit the shareholder to control the participated company or to hold a substantive corporate connection, according to Art. 2359 of the Italian civil code.

15 In such a way that a capital gain for the transferring company could arise only whether and to the extent to which the receiving company decides to account the assets received at higher values than they had before. See art. 3 of D.Lgs. 358/1997.

16 Directive 90/434/EEC, amended several times and lastly restated by the Directive 2009/133/ EC.

17 The same scheme applies to „exchange of shares”, through which the receiving company acquires or enhances its participation in the target company to the extent of gaining its control.

18 According to paragraph 2-ter of Art. 176, the receiving company has the right to enhance tax 
in turn leads to a situation of ,taxes as motivators” of company restructuring, offering scope for tax arbitrage.

Interestingly enough, the path so far described, which focuses mainly on the Italian tax system, is quite common across the Member States, whose legislations have roughly developed from the taxation of capital gains accrued on the assets of merging or transferring companies, to the succession principle and tax neutrality granted to company restructuring.

\section{THE MERGER DIRECTIVE AND ITS ENDURING INFLUENCE ON TAXING DOMESTIC COMPANY RESTRUCTURING}

The building of the common market raised the need to lower tax barriers and discrimination between cross-border and purely domestic business restructurings. Before the Merger Directive, cross-border corporate restructurings - if ruled at all by the Member States' company law - were by and large treated as taxable events, whereas the capability of the State of the transferring or acquired company to tax the „hidden reserves" could fade away. ${ }^{19}$

In that event, an unconditional tax-neutral regime would go too far, hampering permanently the power to tax with regard to the accrued capital gains of assets ending up in a non-resident acquiring company. The need for a compromise between the objective of removing tax obstacles in cross-border restructuring on the one hand, and the safeguarding of the financial interests of the Member States on the other, has been satisfied by requiring, for the tax relief, that assets and liabilities be connected to a permanent establishment of the acquiring company in the origin State and kept for tax purposes at the same values they had before.

In the pursuit of a suitable tax-neutral regime for company restructuring, as

values of both tangible and intangible assets applying, to the difference between such values and the ones recorded in the books, the substitute tax of 12 to 16 per cent (depending on the amount affranchised) instead of the ordinary corporate tax rate (24 per cent) and the regional business tax (3.9 per cent).

19 In the Advocate General Sharpston's opinion delivered on 6 November 2008, Case C-285/07, A.T., par. 1, «when the assets of one company are transferred to another in the course of a corporate restructuring operation, that can result in taxable event. The transfer constitutes a disposal for the purpose of capital gain tax and, if those assets have increased in value since the transferor originally acquired them, a chargeable gain may arise. Some Member States provide for relief by allowing deferral of any immediate charge to tax since the assets are not in fact realized. However, relief is rarely granted where the transfer is to a non-resident company, for fear that the payment of tax may be avoided altogether rather than simply being deferred». See also Lang, M., et al., Introduction to European Tax Law: Direct Taxation, $4^{\text {th }}$ ed., 2016, Linde, Wien, p. 158: „reorganizations - in absence of any specific tax provisions - will generally trigger taxation of unrealized capital gains. For domestic reorganizations Member States typically provide for tax deferrals of the capital gains tax levied on the hidden reserves of the transferred assets under their domestic tax law. Often, losses not yet utilized by the transferring company may also be carried over to the acquiring company. Therefore, domestic reorganizations are tax neutral... Similar tax provisions for reorganizations of companies of different Member States are necessary for the completion of an internal market within the European Union". 
we have seen before, the Merger Directive has played an overall prominent role. Although intended to address cross-border transactions, it has influenced in many ways the Member States' legislations also on their domestic spheres.

On the one side, the Directive set the boundary of corporate restructuring by fostering the enactment of corporate operations in the Member States' company law. When the Directive was enforced, some Countries did not even have specific rules for mergers, the effects of which were obtained indirectly. ${ }^{20}$ As for the concept of „division”, foreseen by the Sixth Directive, no. 82/891/CEE, this was far from being a common heritage in the Member States, some of which would hardly conceive the division or demerger as a specific kind of corporate restructuring. ${ }^{21}$

Furthermore, many domestic legislations did not foresee - or allow at all mergers or divisions involving the absorption of a national company into a foreign one, as such operations entail the transfer of the registered headquarters and a change in the nationality of the transferring company, whose substantive effects could take place only as a result of the liquidation of the transferring company..$^{22}$

Secondarily, the Merger Directive encompassed in the qualified operations to rule both the ,transfer of assets" (id est the transfer of a branch of activity) and the „exchange of shares", thereby upholding their belonging to ,corporate reorganizations" and thus deserving of tax deferral on the accrued capital gains. Actually, if the ,transfer of assets" identifies a particular kind of contribution in kind, the „exchange of shares” was not previously defined in the Member States' civil or tax law, which indeed were influenced by the Directive's legal definition, as it happened in Countries ${ }^{23}$ where the concept was previously unknown, with the exchange of shares being treated as a simple taxable alienation of shares..$^{24}$

Even more importantly, the Merger Directive outlined a kind of benefit - the roll-over relief - which marked the path for the forthcoming tax treatment of purely domestic company restructuring, at the same time picking up on the legacy of certain Member States, which already provided for the succession principle as a tax-neutral

20 As for instance in Ireland or in Belgium, where before the early 1990s the merger was not foreseen, while its effects could be reached indirectly through the winding up and dissolution of the companies involved, the transfer of all the assets and liabilities to a newly created company (by the liquidator) in exchange of his shares, the distribution of the shares to the shareholders of the liquidating companies in exchange of their own shares, and finally the dissolution of the two companies. As liquidation, the capital gains accrued on the assets of the transferring company were taxed. See Wijnen, W.F.G., Survey of the Implementation of the EC Corporate Tax Directives, IBFD, Amsterdam, 1995, pp. $78 \mathrm{ff}$.

21 In Italy, for instance, the division was regulated only once the D.Lgs 22/1991 implemented the aforementioned Sixth Directive, but the same happened in other countries, like The Netherlands.

22 This is somewhat true for Belgium, Denmark, France, Germany, Luxembourg. See Wjinen, W.F.G., op. cit., passim.

23 Like Belgium, Italy, Greece, Luxembourg and Portugal.

24 The „exchange of shares" was probably included in the qualified operations listed by the Merger Directive considering that, in a few countries (such as Ireland and United Kingdom), mergers and divisions took the form of a take-over and an exchange of shares, and not as an amalgamation of corporate assets and liabilities into one legal entity. The ECJ, accordingly, considers that Art. 2.d of Directive 90/334/CEE „defines mergers by exchange of shares" (Case C-28/95, par. 35). 
alternative to subject-to-tax alienation or liquidation. ${ }^{25}$

The 7th recital of the MD states that the ,system of deferral of taxation of the capital gains relating to the assets transferred until their actual disposal, applied to such of those assets as are transferred to that permanent establishment, permits exemption from taxation of the corresponding capital gains, while at the same time ensuring their ultimate taxation by the Member State of the transferring company at the date of their disposal".

This sheds light on the reasons for tax neutrality also at a domestic level. The capital gains accrued on the assets transferred as a result of mergers and divisions can benefit from deferral simply because taxation is postponed upon the disposal of the assets and not definitely ruled out, as it would happen should the link between the assets and the domestic corporate tax break up as roughly happens without a permanent establishment, or - in purely domestic operations - when the incorporating legal entity does not qualify for the application of business tax.

All of this is not overshadowed by the fact that cross-border mergers or divisions are infrequent, both due to the Member States' reluctance to allow the loss of nationality of the transferring company and to the incomplete harmonization of company law, which has long hampered intra-community corporate reorganizations.

Notwithstanding the harmonization brought about by the Cross-Border Merger Directive 2005/56/EC, ${ }^{26}$ the most common way to carry out an acquisition is still by means of a share deal, where the participation in the target company is acquired (sometimes after the branch of activity is spun off through a division or a contribution in kind to a new company), or through an asset deal, with the undertaking acquired by the foreign holding or by a local company set up by the acquiring group.

Generally speaking, acquisitions - even purely domestic ones - seldom take place by means of a merger/division of the target company into the acquiring company, with integration between different groups of shareholders. Rather, are carried out through the purchasing of the majority of the shares of the target company, which could also be created on purpose by carving out ${ }^{27}$ the target undertaking among those belonging to the vendor.

In this scheme the merger, if any, follows the acquisition, being deliberated within the acquiring group ${ }^{28}$ as a more efficient allotment of branches of activity, reducing-cost tool, and final step of the take-over process. And even when the operation takes place in the form of an ,asset deal”, involving the selling of a going

25 Reference should be made, for instance, to Denmark, Greece, The Netherlands, Portugal, the United Kingdom. It is questionable, therefore, whether the Merger Directive entails a deviation from the realization principle allegedly prevailing in all Member States, as asserted by Englisch, J., National measures to counter tax avoidance under the Merger Directive, Oxford University Centre for Business Taxation, WP 11/13, p. 1.

26 On the topic, which cannot be addressed here, see Bech-Brune/Lexidale, Study on the Application of the Cross-Border Merger Directive, 2013; Dutcik, M., The legal analysis of mergers and acquisition in the EU. Does it get us where we want to be?, http://arno.uvt.nl/show. cgi?fid=143831.

27 By means of a contribution of a going concern or a division into a new company whose shares are then sold to the acquiring group.

28 Where it often takes the form of a merger by absorption of a fully-owned subsidiary. 
concern, the acquisition is more often conducted not directly from abroad (in such a case, a permanent establishment of the foreign company would arise in the other State), but through a vehicle incorporated in the same jurisdiction in which the assets are located. ${ }^{29}$

Within this general framework one major exception can be made for the, exchange of shares", defined by Art. 2.e MD as ,an operation whereby a company acquires a holding in the capital of another company such that it obtains a majority of the voting rights in that company, or, holding such a majority, acquires a further holding, in exchange for the issue to the shareholders of the latter company, in exchange of their securities, of securities representing the capital of the former company".

The inclusion of the exchange of shares under company restructuring is everything but trivial if we define „company restructuring” as only those operations involving a change in the corporate legal structure and net wealth (mergers, divisions) and in corporate assets (transfer of a branch of activity). With the exchange of shares, instead, the act of restructuring takes place at the shareholders' level, whilst at the corporate one the ,exchange" entails an increase in the company's share capital.

Although it determines a shift in the controlling shares of the target company, the exchange hardly concerns the organization of the business. However, it is nonetheless an operation that affects the shareholding structure, with sound grounds for granting tax relief. ${ }^{30}$ It is also worthwhile noting that in many Member States the exchange of shares is considered as an indirect form of merger, where the merger process involves the companies' holdings (stock-for-stock merger, or stock swap), not the corporate assets.

In order to achieve the intention of the Merger Directive (to shield cross-border operations from restrictions or disadvantages arising from the tax provisions of the Member States involved), those operations are granted roll-over relief, meaning that the allotment of securities representing the capital of the acquiring company to a shareholder of the acquired company (in exchange for securities in the latter company) shall not give rise to any taxation of the capital gains of that shareholder (Art. 8.1 MD), provided that the shareholder does not attribute to the securities received a value for tax purposes which is higher than the value the exchanged securities had immediately prior to the exchange of shares (Art. 8.4 MD).

A prominent reason of interest in the ,exchange of shares" is indeed a fiscal one. Through such an operation, the shareholders of an operating company resident in one Member State put between them and the participated company a sub-holding resident in a different Member State. Here, an advantage of doing so is if the latter State has enforced a (more favourable) regime of participation exemption, which can be exploited in a subsequent sale of the shares of the operating company. The matter requires further investigation in the light of tax-avoidance issues brought up by company restructurings as tools for minimizing taxation on the subsequent sale of

29 Actually, in many practical handbooks on "taxation of cross-border mergers and acquisitions" that address the most common legal means for acquisitions, cross-border operations such as mergers and divisions are not even mentioned.

30 Stevanato, D., Le riorganizzazioni internazionali di imprese, in Diritto tributario internazionale, edited by V. Uckmar, Cedam, Padova, 2005, p. 548. 
the shares.

\section{TAX AVOIDANCE CONCERNS IN REGULATING COMPANY RESTRUCTURING}

As they play an important role in underpinning corporate restructuring, tax motives pose a key question: to what extent does the attempt to obtain some tax benefits undermine the feasibility of the related transactions, raising tax-avoidance issues and risks of challenges by the tax authorities.

Admittedly, company restructuring has always been linked to tax avoidance, as it was in the U.S. leading case Gregory vs. Helvering, ${ }^{31}$ where the Supreme Court established, with a far-reaching decision, that notwithstanding ,the legal right of a taxpayer to decrease the amount of what otherwise would be his taxes, or altogether avoid them, by means which the law permits", the capacity of a business reorganization to affect tax liabilities is subject to the business purpose test and must have an economic substance and not be merely a tool for reducing tax.

Indeed, even in the last recital of the Merger Directive, Member States may refuse to apply the provisions of the Directive if the corporate operations carried out have tax evasion or tax avoidance as their objective or one of their principal objectives.

More recently, the Council of the European Union has issued a Directive laying down rules against tax avoidance practices which impair the functioning of the single market and which could affect also business integrations and corporate restructurings. ${ }^{32}$

In Italy too, the first GAAR (General Anti-Avoidance Rule) was focused on and limited to business restructuring, just as Art. 15 (formerly Art. 11) MD is. Aware of the great discretionary power that a GAAR would have entitled the tax authority, Parliament carefully limited the scope of the tax avoidance rule to operations of corporate restructuring. ${ }^{33}$

There certainly was no desire to assert that company restructuring entails tax avoidance per se, but that a tax avoidance challenge could be filed only if one of the listed operations (spin-off, merger, sale of a business, and so on) have occurred. Nevertheless, although intended to limit the powers of tax offices, the reference made by the Italian first mini-GAARs ${ }^{34}$ stems from the extensive exploitations of corporate

31293 U.S. 465, 466, decision of 7 January 1935.

32 The wording of Art. 6 of Directive 2016/1164 of 12 July 2016, namely of the general anti-abuse rule, is somewhat similar to Art. $15 \mathrm{MD}$ : „1. For the purposes of calculating the corporate tax liability, a Member State shall ignore an arrangement or a series of arrangements which, having put into place for the main purpose or one of the main purposes of obtaining a tax advantage that defeats the object or purpose of the applicable tax law, are not genuine having regard to all relevant facts and circumstances. An arrangement may comprise more than one step or part. 2. For the purposes of paragraph 1, an arrangement or a series thereof shall be regarded as nongenuine to the extent that they are not put into place for valid commercial reasons which reflect economic reality".

33 See Art. 10 of Law 408/1990, which first made reference to economic operations (concentration, spin-off) rather than to juridical deeds (merger, division, contribution in kind, and so on).

34 Art. 10 of Law 408/1990 was substituted by Art. 37-bis of Pres. Decree 600/1973. 
reorganizations as strategies for reducing taxes in ways that fall outside the statutory scope for which tax neutrality is granted. ${ }^{35}$

A few examples may illustrate this. Before the full acknowledgment of the rollover relief in the years to come, contributions of undertakings were at first ruled so as to suspend taxation of capital gains for the transferring company, while allowing the receiving company to step up the values of the assets for tax purposes, thereby creating an incentive for carrying out operations even without any real business purpose.

Similarly, the long-standing exemption of an individual's capital gains ${ }^{36}$ would trigger the selling of the shares to a New-Co owned by the same shareholders, which then was merged by incorporation into the former, with subsequent allocation of the purchase price on the assets of the merged operating company and tax-free increasing of their values. Not to mention mergers of non-operating companies acquired only for their heritage in terms of non-exhausted losses.

All in all company restructurings, mainly due to their tax-neutral regime, have steadily been used as tools for exploiting tax benefits and loopholes, sometimes far beyond the scope of the law, to the extent that they have become a main field for antiavoidance tax regulation.

The matter requires more in-depth attention however, by making a distinction between tax breaks embedded in the very statement of the rules, and loopholes resulting from a mischievous use of legal means in order to reap tax results beyond the spirit of the law.

As an example of the former, the foregoing regulation of contribution of undertakings granting the deferring of capital gains tax, while allowing the transferee to raise the assets' value for tax purposes without any payment, or with a payment at a reduced tax rate. In such a situation, tax breaks can hardly be considered as unintended consequences of the law, being rather the outcome of the legislative choices.

This further clue leads us to discuss the boundary between the reduction of a tax burden „by means which the law permits” as an unalienable legal right of the taxpayer, and tax avoidance. Focus first must be put on the concept of tax avoidance as circumvention of the spirit of the law; and subsequently on the role of the business purpose.

\section{CORPORATE RESTRUCTURING AND THIRD-PARTY SALE}

The implementation of one or more corporate-restructuring operations - such as divisions, contribution of branches of activity, exchange of shares etc. - may be motivated by the attempt to remove or reduce tax burdens related to the selling of the business, in whatever form it takes place. The key point is that the amount of taxes to pay is often strictly related to the patterns chosen by the taxpayers, meaning

35 After all, the business purpose doctrine in challenging transactions motivated by tax avoidance arose within the context of reorganizations, and was later extended to other areas: Waizer, H., Business Purpose: The Effect of Motive on Federal Income Tax Liability, Fordham Law Review, 49, 6, 1981, p. 1078.

36 In Italy it was only following Law 102/1991 that capital gains realized by individuals was actually taxed as realized income. 
that, other things being equal, the legal solutions that minimize tax liabilities for both parties of the deal will be preferred. It is nonetheless true that other priorities of civil, commercial or other natures, could prevail in choosing a tax arrangement more burdensome than others.

Nevertheless, tax reasons are rarely the sole driver of company restructuring. More often, they are intertwined with business purposes, which may or may not be the predominant factor in the choice of the operations.

This is true in particular when selling is the ultimate aim of the corporate restructuring. It would be naive, indeed, to consider the latter an unnecessary step and an illegitimate use of private autonomy. For instance, it could be suitable to carve out the business to sell into a new company in order to open the capital to new partners who are not interested in other activities of the selling group. In other situations, the acquiring company may prefer a share deal to an asset deal as a matter of civil responsibility. It is also true, though, that corporate restructuring could be triggered by the desire to reap tax savings, thereby raising issues under anti-avoidance regulations.

From this perspective, the contribution or the demerger of a branch of business could give rise, for example, to such an issue. Consider an asset deal producing taxable money-income compared to a share deal qualifying for participation exemption or for a reduced tax rate. It could be stated, as the Italian tax authority did for a long time, that a demerger followed by the selling of the shares of the receiving company falls within the tax avoidance rule when the individual income tax faced by the shareholders is lower than the business tax that would have been paid on the transfer of corporate assets for a consideration. ${ }^{37}$

As to corporation tax, it is worthwhile noting that, following the participation exemption enactment, Art. 176 of Italian ITC states clearly that the tax-neutral contribution of a branch of activity followed by the disposal of the shares received in exchange does not qualify as an avoidant scheme.

The rule sheds light on the very nature of tax avoidance in terms of circumvention of the spirit and scope of the law, which does not recur when taxpayers choose, from among the legal instruments at their disposal, the one able to achieve their business purposes at the same time reducing the related tax burden. In the recent words of the Italian tax administration, ,the transfer of a branch of activity may take place through a direct transfer or an indirect transfer. In the first case, the company which owns the business sells it directly to the buyer, realizing a taxable capital gain or a deductible capital loss... The purchaser is entitled to set the assets for tax purposes at the transfer value... In the second case, on the contrary, the shareholders of the company owner of the business may sell their shares, realizing a capital gain which could be tax exempt (if participation exemption applies) or taxed at the rates foreseen

37 For a while, the Italian ITC considered the demerger of single assets as non-compliant with the anti-avoidance rule, on the assumption of a subsequent sale of the shares at a lower tax rate. Although the rule has been cancelled, the low tax rates that would apply for a long time to capital gains earned by individuals was a sound reason for the tax authority to challenge demerger and subsequent disposal of the shares as an abusive tax scheme. The premise of that opinion has fallen since the tax hike on individual capital gain and the reduction of the corporation tax rate put them at a roughly similar level. 
for individuals... Unlike the direct sale of the undertaking, the share deal does not entitle the purchaser to book the assets of the company sold at market value ... These two different tax regimes, as for the transfer of a business... represent alternatives which, although involving different tax burdens and values, are made available to taxpayers to pursue their business purpose, and therefore the tax benefit concerned cannot be classified as undue." 38

The above seems to be quite a general achievement. Similar statements can be found in the academic literature ${ }^{39}$ as well as in jurisprudential opinions such as the one delivered by the Advocate General of the ECJ in case C-352/08 where, in criticising the distinction between the ultimate commercial aim as ,legitimate" in itself and the route chosen for that purpose as ,abusive”, she stated that „drawing such a distinction between aim and method excessively restricts economic freedom. A whole number of legally permissible set-ups might often be available to enable a legitimate economic proposal to be achieved, some of which might prove to have a more favourable tax regime than others. The fact that the parties ultimately choose the option that is most favourable for tax purposes cannot by itself be sufficient grounds on which to base charges of tax avoidance." 40

The dividing line between attaining tax benefits ,by means which the law permits” and tax avoidance is however blurred, and this apparently affects the judgment on corporate restructuring. Access to the ,,conditional tax neutrality” outlined by Art. 175 of Italian ITC, for instance, ${ }^{41}$ is denied if the shares contributed, which do not qualify for participation exemption, are exchanged for shares which on the contrary qualify for the exemption; hence one could argue that reducing taxes otherwise due on thirdparty selling is beyond the scope of company restructuring, even if the comprehensive picture is anything but clear.

In the various interpretations of the Merger Directive delivered by the ECJ, however, this seems not to be the case. Both transfer of assets and exchange of shares could be exploited, indeed, to shift the undertakings or the shares to sell - through an in-kind tax-neutral contribution - towards a tax jurisdiction where the participation exemption is enacted, or where the latter is more favourable than in the transferring jurisdiction.

38 Resolution no. 97/E, 25 July 2017.

39 Inter alia, Waizer, H., Business Purpose: The Effect of Motive on Federal Income Tax Liability, cit., p. 1086, note 78: „A taxpayer is not legally required to maximize tax... Whatever the [business purpose] doctrine's validity, it should never apply when a taxpayer selects between alternate transactions, such as sale of stock and sale of assets, that have different practical consequences".

40 Cf. Advocate General Mrs. Kokott's opinion delivered on July 2009 in the Case C-352/08, Modehuis A. Zwijnenburg $B V$, par. 44. On the shortcomings of the theory which describes tax avoidance as an abuse of contractual forms in order to obtain tax advantages, rather than focusing on the circumvention of tax rules and principles, see Stevanato, D., Elusione e abuso delle forme giuridiche, anatomia di un equivoco, Diritto e pratica tributaria, 2015, I, pp. 695 ff.

41 As already discussed the foregoing regime provides for the non-taxation of capital gains accrued on securities exchanged provided that the acquiring company maintains the participations received at the same book values they had before. A similar approach has been followed also by German law, see ECJ case C-285/07, 11 December 2008, A.T. 
In the case of a transfer of assets the shares received by the transferring company could be transferred tax-exempt if participation exemption applies, whilst the straightforward sale of the factory would face full taxation of hidden reserves. In the case of an exchange of shares, on the other hand, the shares received by the acquiring company could have access, in a following sale, to an exemption regime not granted to the shareholder. The latter, alternatively, with the exchange could modify the nature of his holding from a non-exempt to an exempt one. In this case, there would possibly be grounds for the Member State to apply Art. 8 paragraph 6 of the Directive, under which the tax relief provided therein ,shall not prevent the Member States from taxing the gain arising out of the subsequent transfer of securities received in the same way as the gain arising out of the transfer of securities existing before the acquisition". This means that the roll-over principle could extend its scope, besides the value for tax purposes of the securities received, to preserve unchanged the State-of-origin's previous right to tax the hidden capital gain. ${ }^{42}$

Even if the foregoing would in many cases lead only to a deferral and not to a permanent tax break, the questions are whether such events (transfer of assets or exchange of shares within the same group of shareholders followed by the transfer of the shares to a third-party) still qualify as company restructuring according to the definitions and the scopes of the Directive and, if so, whether the tax benefits attained could represent an infringement of the anti-abuse clause which the Member States are entitled (if not advised) to enforce when it appears that one of the operations involved „has as its principal objectives tax evasion or tax avoidance" (Art. $15 \mathrm{MD}$ ).

According to the ECJ it seems that both questions deserve a positive answer, since an integration of different groups of shareholders or a modification in the chain of company's control, as well as an enduring relationship between the acquiring and the acquired company, are not required ${ }^{43}$ From the foregoing, one might argue that company restructuring aimed at a subsequent third-party selling is still Directivecompliant. The conclusion could however be controversial, since the scope of the Merger Directive is to allow enterprises to adapt to the requirements of the internal market in order to enhance their productivity and international competitiveness, much less to grant substantive tax advantages, albeit in terms of tax-deferral, in case a capital gain is realized as a consequence of a third-party sale. ${ }^{44}$

Furthermore, quite often the difference between a matter of interpretation and one of tax avoidance on the issue we are addressing, may be very subtle. Consider the case C-321/05, ${ }^{45}$ in which the ECJ faced the problem raised with regard to an

42 As we've seen before, according to Art. 175 and 177 of the Italian ITC, tax deferral is ruled out (and capital gains immediately taxed) if the securities received in exchange are differently entitled to tax exemption. On this point, it can be noted that the Merger Directive is more compliant with the proportionality principle since it does not impair the right to roll over relief, and merely puts a backstop on subsequent transfer of securities for consideration.

43 Case C-28/95, 17 July 1997, Leur-Bloem.

44 According to the opinion of Advocate General Kokott, Case C-321/05, par. 59, ,an exchange of shares by which it is sought purely to attain tax advantages does not serve a valid commercial purpose within the meaning of the Directive".

45 ECJ case C-321/05, 5 July 2007, Kofoed. 
exchange of shares that was shortly afterwards followed by a distribution of dividends from the acquired company to the acquiring company, and then from the latter to the shareholders.

Whilst the shareholders considered the exchange of shares exempt from tax according to the Merger Directive, the tax authority challenged that statement, taking the view that the distribution of dividends formed part of the consideration paid for the exchange of shares, and that as this sum exceeds the threshold to qualify for Art. 2.d of the Directive, the exemption should be denied.

Aside from the question of interpreting what should be considered as „cash payment" being part of the consideration for the acquisition, the Kofoed case raised a crucial point for grasping the spirit of the law of the Merger Directive. Its direct purpose, namely to lower barriers to cross-border restructuring of undertakings, is fulfilled ,, by ensuring that any increases in the value of shares are not taxed before they are actually realised and by preventing operations involving high levels of capital gains realised on exchanges of shares from being exempt from income tax simply because they are part of a restructuring operation." ${ }^{46}$ This last concern is in accordance with the other milestone on which the Directive is founded, that is to ensure the State-of-origin ultimate taxation of capital gains arising upon disposal of the shares, as one of the Directive's recitals reads.

The instrument of tax deferral outlined by the Directive should not therefore be exploited to exempt capital gains altogether, dropping the power to tax originally granted to the State where the transferring company or the shareholders of the acquired company are located for tax purposes. ${ }^{47}$

In purely domestic situations too, corporate restructuring as a means of transferring assets with a reduced taxation could be seen as abusive or framed, for tax purposes, within a different legal scheme from that elected by the parties, as in the interpretation of the Italian Court of Cassation within the realm of registration tax.

At first, the Court assessed the application of the proportional registration tax (instead of the fixed amount) to the contribution of a branch of activity followed by the selling of shares in the acquiring company, as if it was a direct sale of the factory, on the supposed need to interpret tax law according to the economic substance underlying the legal transactions and the contractual links. ${ }^{48}$ The foregoing opinion, based on a rule of the registration tax law which assigns a prominent role to the very

46 ECJ, case C-321/05, point 32.

47 As recently stated by ECJ in Joined cases C-327/16 and C-421/16, 22 March 2008, Marc Jacob and Marc Lassus, par. 50, ,the purpose of that fiscal neutrality is not however to avoid such a capital gain from being taxed by the Member States with fiscal competence in respect of that gain, but only to prohibit them from considering that exchange as the chargeable event for the purposes of taxation".

48 Inter alia Cass. 25487/2015 and 6758/2017, according to which the real intention of the parties and the very nature of the legal transaction should be taken into account for tax purposes, so that the contribution of a business of activity for shares and the following sale of the shares by the transferor to a third party shall be qualified as a direct transfer of the business assets to the purchaser of the shares if, in looking at the comprehensive operation, the aim of a transfer of assets can be envisioned. These judgments recall the US step transaction doctrine. 
nature and the legal effects of the deeds submitted to registration, ${ }^{49}$ is the result of an evident misunderstanding: the aforementioned rule means to frame correctly the contracts submitted to registration, notwithstanding the name or the form used by the parties. If these forms are incorrect, obviously they need to be discharged and substituted for tax purposes; however this does not involve any primacy of economic effects, since the law clearly states that „legal effects" do matter.

In a subsequent and even more radical vision regarding registration tax applicable, the Court altogether denies any distinction between the share and the asset deal, on the basis of an alleged functional identity of the sale of the entire shareholding with the sale of the assets belonging to the company whose shares have been sold, addressing the substance over form doctrine. ${ }^{50} \mathrm{In}$ the opinion of the Court, as tax provisions aim to collect revenues from facts expressing wealth, they should be interpreted consistently with their very nature. However, what remains unclear is why, given two or more legal patterns mirroring a certain economic result, taxation should be always settled on the more burdensome one, superseding the choices embedded in the legislation. It is indeed quite naive to establish an identity between an economic result and a legal scheme representing the „model” to follow and the benchmark to which to trace back the taxes to pay, and hence to consider any other legal path allegedly aiming at the same economic result as tax-avoidant. ${ }^{51}$

This point involves some more in-depth examination of the tax-avoidance rules and will be addressed more extensively in the paragraphs below.

Up to that point, what can be asserted is a more straightforward approach to corporate operations such as mergers or divisions not aiming at a real „reorganization” of branch of activities, as could happen when the above mentioned operations are used to allot real estates or single assets, material or immaterial, within a group of companies, as a preliminary step to a share deal exploiting the participation exemption and the like. In other words, if fiscal neutrality has become the natural regime for reorganizations of undertakings, things run differently when single assets are involved in corporate operations.

On this issue there are reasonable grounds for believing that company restructuring such as mergers and divisions, although tax-neutral irrespective of what has been transferred, could hardly be exploited to ease an exempt or tax-reduced share deal without having to face a tax-avoidance challenge. It is one thing to admit as an equivalent share deal to asset deal in case of a transfer of a branch of activity, given the legislative trend to ease corporate reorganizations as a means of efficient allocation of manufacturing facilities and factories; but it is a very different thing to exploit a tax-neutral scheme (and of course, if any, loopholes) in order to avoid the ordinary taxation on any asset disposal whatsoever, channelled through a share deal. ${ }^{52}$

49 See art. 20 of Pres. Dec. 131/1986.

50 Cass. 24594/2015; 11877/2017. Given the alleged „economic” identity between the sale of the entire shareholding and that of the branch of activity run by the company, both intended to transfer the right to use and to dispose of the undertaking from one group to another, registration tax should be assessed consequently.

51 See Stevanato, D., Elusione e abuso delle forme giuridiche, cit., passim.

52 It is useful to remember, for instance, that the Italian participation exemption is not granted 


\section{CORPORATE RESTRUCTURING AS A MEANS OF LOWERING TAXES WITHIN THE SAME PARTICIPATING GROUP}

So far, we have addressed corporate restructuring as a means to channel the sale of an undertaking in that it reduces taxes otherwise due.

Corporate restructuring could however be used to minimize the taxes currently borne by the restructuring group itself, out of any purpose of a transfer to a third-party. The tax-neutral features of mergers, divisions, transfers of assets and the like could be seized to devise strategies aimed at reducing overall tax liabilities. Some examples may shed light on this topic.

As discussed above, in the past it was quite common to come across special laws that would allow, through a contribution of a branch of activity, a tax-free revaluation of the assets transferred to a controlled company. Currently, Art. 176 of the Italian ITC, within a tax-neutral scheme for contributions of undertakings, grants the acquiring company the option of paying a reduced tax on the difference between the book and market values of the fixed assets received, and from that point forward to deduct amortization and depreciation on the increased values so as to reduce taxes on future income.

For a paradigmatic example of exploitation of loopholes, take the „family buyout" widely used at times when an individual's capital gains were not taxed at all. In that scenario, the merger between the new company and the old operating company whose shares had been transferred to the former, granted the carryover of the acquisition cost of the securities (transferred tax-exempt by the individual shareholders) on the assets of the company merged by absorption. Indeed, the cancellation deficit in the merger process (i.e. the excess of the cost of the shares to be cancelled compared with the book values of the subsidiary's assets) was at that time an amount recognized for tax purposes.

Furthermore, it has to be considered that transfers of rights and entitlements connected to mergers and divisions are commonly used to avoid or postpone tax liabilities otherwise due, as happens exploiting losses carry-over of a company merged by absorption, or through a merger instead of a liquidation of a controlled company to obtain its reserves without paying taxes on dividends..$^{53}$

There is no doubt that the compensation of losses is strictly inherent to mergers and divisions, being one of the rights pertaining to the incorporating company as universal legal successor of the incorporated company: accordingly, tax credits, losses, carry-forwards and the like are in that way transferred from one legal entity to another. However, according to the legal traditions of many Member States, losses carry-over is somewhat limited or denied when the acquired company no longer carries out

if the company concerned, whose shares are being sold, doesn't run an undertaking, as it is presumed when it owns mainly immovable property (see Art 87 ITC). Also, company restructuring having, as a result, the creation of a corporate vehicle addressee of single assets to be sold through the transfer of the shares, discussed above with regard to divisions, has been often considered as an abusive scheme.

53 This obviously does not mean that such a choice should be considered as tax-avoidant. See Englisch, J., op. cit., p. 20. 
any activity at the time of the merger. This seems a plain application of the business purpose doctrine, which considers as tax avoidant any operation lacking commercial reasons, as it is the merging of a company that has ceased its activity. ${ }^{54}$ This issue is however more nuanced. Indeed, the exploitation of carryover losses within the same group is admitted within tax consolidation or group relief regardless of the activity (if any) currently carried out by the surrending company.

Again, non-proportional demerger is a common and legitimate way to pursue the breakup between shareholders interested in the different activities carried out by the demerged company, without taxation on the accrued capital gains that would otherwise arise in the case of a proportional demerger followed by a share swap deal.

In all these cases tax motives could well be the principal (if not the only) objective of the corporate restructuring, which can sometimes be argued by the fact that, after the operations, the corporate and shareholder structures remain substantially unchanged (in other words, by the „circular" nature of the construction). However, this would be too little a ground to assess a tax-avoidance scheme. Indeed, the very nature of tax advantages enjoyed by the taxpayers - in other words, if they qualify as „abusive" or as a legitimate way for reducing taxes - cannot be established only on the basis of the alleged lack of a business purpose, as we will briefly discuss in the next and final section.

\section{TAX AVOIDANCE AND COMPANY RESTRUCTURING: THE UNEASY ROLE OF BUSINESS PURPOSE}

In addressing corporate restructuring, tax avoidance is quite an involved topic. This is due overall to the inherent uncertainty embedded in expressions like ,abuse of law” or "tax avoidance”, as things to be set apart from tax planning as a legitimate practice, that is the reduction of taxes "by means which the law permits". This uncertainty becomes all the more serious in corporate restructuring schemes, mainly for two supposedly divergent reasons. On the one hand, business reorganizations are granted some sort of tax relief, mainly in the form of capital gains tax deferral, which could be esteemed as benefits or tax breaks compared to those being applied in the ordinary course of business. On the other, restructuring involves - almost by definition - some changes to the corporate statutes and assets as well as to the shareholding structure, so as to meet the „business purpose” test on which tax avoidance rules commonly rely.

Both the foregoing points need to be addressed in greater depth.

First, it is very arguable to consider fiscal neutrality inherent to corporate operations as a kind of tax advantage. As discussed before, tax-neutrality of mergers

54 See also ECJ, case C-126/10, 10 November 2011, Foggia - SGPS. The point cannot be extensively addressed here, but we can observe, across the different legal systems, a trend in considering business losses as strictly linked to the group, legal entity or undertaking within which they have accrued. Hence, the transfer of losses as a consequence of a company restructuring in the absence of a going concern of the transferring entity, is targeted by specific or general anti-avoidance clauses. 
and divisions, for instance, is consistent with the legal concept of income, so far as it excludes unrealized capital gains from the taxable base, and with the very nature of mergers and divisions, which are far from being operations entailing the ,transfer of assets" to a third party, let alone for a consideration.

As for business purpose, in theory any corporate operation has one, since after the merger, division, contribution in kind, or whatever, the outcome is different, in terms of corporate holding and shareholder structure, with respect to what it was prior to completion of the process. However, this is true only from a very formal perspective: what needs to be ascertained is whether the corporate operations have brought about substantive modifications in terms of reduction of costs, efficiency, financial structure, opening of the capital to third-party, and so on. ${ }^{55}$

Very briefly, some key points should be laid down in order to correctly identify the rule of business purpose in tax avoidance reasoning, and regarding the actual nature of what can be considered abuse of tax law.

It could be superficially asserted that tax avoidance is the absence of business purpose in making arrangements or in deciding corporate restructuring. In other words, that transactions without a business purpose are therefore motivated by tax avoidance. ${ }^{56}$ This would however be far from true. The lacking of business purpose is, at the most, only a symptom of a possible abuse of tax law, which depends upon a very different element, namely on the outflanking of the spirit of the law.

This idea is to an extent laid down by Art. $15 \mathrm{MD}$, which reads as follow: ,the fact that the operation is not carried out for valid commercial reasons such as the restructuring or rationalisation of the activities of the companies participating in the operation, may constitute a presumption that the operation has tax evasion or tax avoidance as its principal objective or as one of its principal objectives. " However, the reference to ,presumptions" is, in such a context, misleading as it conveys the idea that, in the absence of commercial reasons, the onus of proving the legitimacy of the operations should fall upon the taxpayer. Admittedly, the absence of a valid commercial reason is far from conclusive as it is not a proxy for tax avoidance, which requires a circumvention of the purpose of the law. It appears, therefore, to be more consistent to consider the lack of valid commercial reasons as a hint for a closer examination of the individual case, whereas tax avoidance must be demonstrated on wholly different grounds, namely arguing the breach of the spirit of the tax law.

55 Along this line ECJ, case C-126/10, Foggia - SGPS. While affirming that ,a merger operation based on several objectives, which may also include tax considerations, can constitute a valid commercial reason provided, however, that those considerations are not predominant in the context of the proposed transaction" (par. 35), the Court points out that ,the cost savings resulting from the reduction of administrative and management costs, when the acquired company disappears, is inherent in any operation of merger by acquisition as this implies, by definition, a simplification of the structure of the group” (par. 48); however, „by automatically accepting that the saving in the cost structure resulting from the reduction of the administrative and managements costs constitutes a valid commercial reason, without taking account of the other objectives of the proposed operation, and particularly the tax advantages, the rule set out in Article 11(1)(a) of Directive 90/434 would be entirely deprived of its purpose".

56 See Waizer, H., op. cit, p. 1078, who notes that „business purpose is usually considered the exclusive alternate motive to tax avoidance". 
Business purpose, in other words, is not a strong signal as its absence does not per se imply any assumption on the nature - legitimate or non - of the tax benefits involved. On the other hand, valid commercial reasons, if any, could co-exist with distortive tax advantages, which actually, from a purely theoretical viewpoint, should be dismissed, but which in fact are not denied according to the traditional trend in conceiving tax avoidance, long-since established across the legal systems of EU Member States. In other words, although a circumvention of the spirit of the law should occur, the positive allegation of a business purpose forestalls any tax avoidance challenge.

Irrespective of any economic substance, the pursuit of a tax mitigation is unchallengeable as far as it is in line with the spirit (and of course the letter) of the law, as is the case when the taxpayer makes a choice between alternatives clearly endowed by the legal system..$^{57}$ Tax benefits, therefore, may well be a legitimate reason for company restructuring, out of any abuse of law indictment, as the ECJ has correctly affirmed in interpreting the Merger Directive..$^{58}$

\section{CONCLUSION}

Domestic company restructuring has long since gained the status of non-taxable events. Notwithstanding the transfer of assets triggered by corporate reorganizations, the lack of a consideration is sufficient reason for tax deferral of unrealized capital gains, the future taxability of which is granted by the continuing business tax regime within the receiving company. Tax deferral can therefore be devised neither as a deviation from the established concept of legal income for tax purposes, nor as a tax break.

In this framework, the rationale for taxing capital gains when cross-border business restructurings are carried out is not inherent to the intrinsic nature of business

57 This occur, giving same examples, with the option for a voluntary substitutive tax granting a mitigation of the burden, or with the choice between asset or share deal, or between winding up a company or merge it through absorption, and so on. See also Englisch, J., op. cit., pp. 16 ff.: ,not every tax advantage that possibly accrues to the taxpayer due to a complex scheme exploiting the gap between, on the one hand, the statutory rule, construed strictly, and, on the other hand, a consistent implementation of statutory purpose, can be denied based on tax avoidance allegations. It is furthermore necessary to distinguish tax avoidance from legitimate tax planning... Equality before the law is thus not impaired by tax planning that exploits legislatively tolerated or willfully created loopholes, rifts or options within the tax system, because the differently taxed situations have to be regarded as dissimilar in the light of the standards set by the legislator". Along the same lines Advocate General Mrs. Kokott's opinion in the case C-352/08, Modehuis, par. 47, where she states that ,the mere fact that in order to achieve a legitimate economic aim a taxpayer chooses, out of several lawful options, the one that is most favourable to it for tax purposes is not by itself sufficient grounds for a charge of tax avoidance within the meaning of Article 11(1)(a) of Directive 90/434".

58 Case C-321/05, Kofoed, par. 30: ,it is clear... from the general scheme of Directive 90/434 that the common tax rules which it lays down, which cover different tax advantages, apply without distinction to all mergers, divisions, transfer of assets or exchanges of shares irrespective of the reasons, whether financial, economic or simply fiscal, for those operations" (see also Case C-28/95, Leur-Bloem, par. 36). 
reorganizations. Rather, it is inherent to preserving the financial interest of the State of the transferring company. Accordingly, tax relief granted by the Merger Directive is in keeping with the above-mentioned principle as the permanent establishment requirement is the equivalent of the continuing business income regime in domestic operations.

The foregoing comments shed light on the fact that tax neutrality should not be seen as a concession to grant only in cases of perceivable restructuring contents. Rather, as the natural regime of corporate operations not involving a cash consideration (like mergers, divisions, stock swaps and so on) as capital gains should not be taxed solely on an accrual basis.

Whatever the case may be, in most situations company restructurings have some kind of valid commercial purpose even if they are prompted by tax-saving motives. If we consider, for instance, demergers or contributions of branches of activities as preliminary steps to a third-party sale in view of the share deal's tax advantages, the lack of a reorganization of the activities involved in the sale (which, at the end of the process, will be owned by a different group along with the more efficient legal structure, including tax outcome, desired by the parties) couldn't be asserted, nor any tax avoidance argued, without the clear identification of the tax rules allegedly circumvented.

Moreover, even corporate operations led by a pure fiscal purpose could be perfectly legitimate and compliant with the anti-avoidance general rules if they are intended to exploit exemptions and preferential regimes embedded within the tax systems, and made available to taxpayers.

\section{LITERATURE}

1. Bech-Brune/Lexidale, Study on the Application of the Cross-Border Merger Directive, 2013.

2. Dutcik, Marija, The legal analysis of mergers and acquisition in the EU. Does it get us where we want to be?, http://arno.uvt.nl/show.cgi?fid=143831.

3. Englisch, Joachim, National measures to counter tax avoidance under the Merger Directive, Oxford University Centre for Business Taxation, WP 11/13.

4. Falsitta, Gaspare, Realizzo di plusvalenze assoggettabili ad imposta di ricchezza mobile nella fusione di società commerciali, Rivista di diritto finanziario e scienza delle finanze, 1964.

5. Lang, Michael, et al., Introduction to European Tax Law: Direct Taxation, $4^{\text {th }}$ ed., Linde, Wien, 2016.

6. Lupi, Raffaelo, Profili tributari della fusione di società, Cedam, Padova, 1989.

7. Stevanato, Dario, Elusione e abuso delle forme giuridiche, anatomia di un equivoco, Diritto e pratica tributaria, I., 2015.

8. Stevanato, Dario, Inizio e cessazione dell'impresa nel diritto tributario, Cedam, Padova, 1994.

9. Stevanato, Dario, Le riorganizzazioni internazionali di imprese, in Diritto tributario internazionale, edited by V. Uckmar, Cedam, Padova, 2005.

10. Turchi, Alessandro, Conferimenti e apporti nel sistema delle imposte sui redditi, Giappichelli, Torino, 2008.

11. Uckmar, Victor, L'imposta di ricchezza mobile sulle plusvalenze patrimoniali, in Aa.Vv., 
La tassazione delle plusvalenze patrimoniali, Cedam, Padova, 1967.

12. Waizer, Harry, Business Purpose: The Effect of Motive on Federal Income Tax Liability, Fordham Law Review, 49, 6, 1981.

13. Wijnen, W.F.G., Survey of the Implementation of the EC Corporate Tax Directives, IBFD, Amsterdam, 1995. 


\section{Dario Stevanato*}

Sažetak

\section{POREZI KAO ČIMBENIK RESTRUKTURIRANJA TRGOVAČKIH DRUŠTAVA}

Među državama članicama Europske unije (EU) postoji uvelike ujednačeni pristup porezno-pravnim aspektima restrukturiranja trgovačkih društava. Potencijalno nametanje poreza na kapitalne dobitke, ocijenjeno štetnim iz perspektive ekonomske učinkovitosti, uglavnom se uklanja propisivanjem posebnih pravila o jamstvu, tzv. porezne neutralnosti. Davanje olakšice odgode plaćanja poreza na kapitalni dobitak u tom je smislu standardno rješenje kad je riječ o transakcijama poput spajanja, pripajanja, podjele društava, prijenosa imovine te zamjene dionica. U tom smislu postavlja se pitanje predstavlja li načelo porezne neutralnosti poslovnih restrukturiranja iznimku od načela realizacije ili refleksiju pravnog koncepta oporezivog dohotka/dobiti. $\mathrm{U}$ potonjem slučaju, porezna tijela mogu odbiti priznavanje relevantnih olakšica $u$ odnosu na transakcije koje nemaju valjani komercijalni smisao, temeljem tumačenja porezno-pravnih propisa ili izričitih protuevazijskih pravila. Pritom valja naglasiti da primjena protuevazijskih pravila mora biti ograničena samo na slučajeve kod kojih se izigrava smisao i duh mjerodavnih zakonskih odredbi.

Ključne riječi: restrukturiranja trgovačkih društava; porezna neutralnost; prekogranična spajanja i preuzimanja; izbjegavanje plaćanja poreza; komercijalni smisao transakcije.

\section{Zussamenfassung}

\section{STEUER ALS ANTREIBER UND ANZEICHEN FÜR UNTERNEHMENSUMSTRUKTURIERUNGEN}

Es scheint ein gemeinsames Muster zu geben, mit welchem die EUMitgliedsstaaten die Besteuerung von Unternehmensumstrukturierungen angesprochen haben. Nach einigen Unsicherheiten wurden die Aktivitäten, welche auf die Unternehmens- und Beteiligungsstrukturen einen Einfluss üben, als Quellen der steuerpflichtigen Kapitalerträge angesehen. Wie man hätte erwarten können, hat das die effiziente Kapitalzuweisung gehindert und zur Erlassung spezieller Gesetze zur Gewährleistung begrenzter und bedingter Steuerbefreiung geführt, um

* Dr. sc. Dario Stevanato, redoviti profesor, Sveučilište u Trstu, Odjel za pravne, jezične, interpretativne i prevoditeljske studije, Italija; dstevanato@units.it. 
Unternehmensübertragungen zu erleichtern, wobei zusätzliche Vorteile öfter als notwendig erteilt wurden. Danach hat man über die Natur der Finanztransaktionen eines Unternehmens tiefer nachgedacht, was zur Erlassung allgemeiner steuerneutraler Bestimmungen für Unternehmensumstrukturierungen führte: den Abzügen für reinvestierte Gewinne (den sog. „Rollover") und dem Aufschub der Besteuerung. Diese durch das EU-Recht zusätzlich verstärkten Bestimmungen sind zum Standard bei Fusionen, Teilungen, aber einigermaßen auch bei Übertragungen der Vermögenswerte und Aktientausch geworden. Es lässt sich darüber streiten, ob diese Steuerneutralität ein Verzicht auf das Realisationsprinzip oder eine Weiterentwicklung des Rechtsinstituts des steuerpflichtigen Einkommens darstellt. Im ersten Fall würden Gründe bestehen, die Steuerneutralität bei Unternehmensumstrukturierungen mit fehlenden wirtschaftlichen Gründen durch zweckorientierte Auslegung oder AntiMissbrauchsklausel infrage zu stellen. Im zweiten Fall sollte man die Regeln zur Bekämpfung der Steuervermeidung begrenzen, um die Umgehung des Gesetzes und des Steuerrechts zu verhindern, ungeachtet des Geschäftszwecks der Transaktionen.

Schlüsselwörter: Unternehmensumstrukturierung; Abzüge für reinvestierte Gewinne; grenzüberschreitende Fusionen und Übernahmen; Steuervermeidung; Geschäftszweck.

Riassunto

\section{TASSE COME MOTIVATORI E PREDITTORI DELLA RISTRUTTURAZIONE AZIENDALE}

L'esame comparatistico sembra evidenziare un percorso comune nell'approccio alla tassazione delle riorganizzazioni societarie da parte degli Stati membri dell'UE. Dopo alcune iniziali incertezze, le operazioni aventi impatto sulle strutture societarie e partecipative sono state considerate fonte di plusvalenze e capital gains. Come ci si poteva aspettare ciò finì per ostacolare una efficiente allocazione dei capitali, ponendo le premesse per l'approvazione di speciali leggi agevolative volte a esentare il trasferimento dei complessi aziendali, a volte con concessione di benefici addizionali non necessari. In una fase successiva, un profondo ripensamento della reale natura delle operazioni di ristrutturazione societaria ha portato all'approvazione di norme generali sulle riorganizzazioni societarie, ispirate al principio di neutralità fiscale: il trasferimento in continuità dei valori e la postergazione della tassazione delle plusvalenze, accolti dalla normativa comunitaria, sono diventati il regime standard di fusioni, scissioni e in una certa misura di trasferimenti d'azienda e scambi di partecipazioni. Si può discutere se la neutralità fiscale garantita alle riorganizzazioni rappresenti una deviazione rispetto al principio del realizzo, o invece uno sviluppo coerente del concetto legale di reddito tassabile. Nel primo caso vi sarebbero argomenti per contestare la neutralità fiscale in operazioni di ristrutturazione privi di ragioni economiche, attraverso interpretazioni finalistiche o regole e principi anti-abuso. 
Nel secondo caso, le regole anti-elusive dovrebbero invece tendere a disconoscere i vantaggi ottenuti aggirando lo spirito delle leggi fiscali, a prescindere dagli scopi economici perseguiti.

Parole chiave: ristrutturazione aziendale; ribaltamento; fusioni e acquisizioni transfrontaliere; elusione fiscale, finalità commerciale. 
